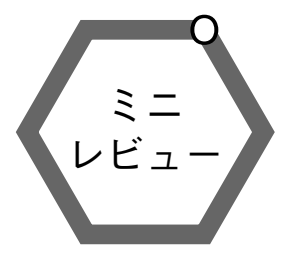

第37回糖質科学懇話会

\title{
ヒト細胞における糖鎖プロセシング酵素活性の可視化 にむけて
}

日本大学生物資源科学部生命化学科 准教授

袴田＼cjkstart航 (はかまたわたる)

Associate Professor, Department of Chemistry and Life Science, College of Bioresource Sciences, Nihon University

Wataru Hakamata

\section{1. はじめに}

20 世紀後半から，糖質は核酸・タンパク質に続く「第 三の生命情報物質」として注目を集めはじめた。今ではそ の機能の重要性は広く認識され, 高校の教科書に紹介され るまでになっている。このような糖質は，比較的短い糖鎖 としてタンパク質や脂質に結合し, 発生, 分化, 癌, 感 染, 炎症, 老化, 生殖, 再生などの多くの生物現象に広く 関わっている。この「第三の生命情報物質：糖鎖」には, タンパク質に結合する糖鎖と脂質に結合する糖鎖があり， タンパク質結合糖鎖は $N$ 結合型と $O$ 結合型がある。本稿 では, $N$ 結合型糖鎖のプロセシングについて簡単に述べ させていただく。

\section{2. $N$ 結合型糖鎖プロセシング酵素と酵素活 性可視化の意義}

真核生物では，非常に多くのタンパク質が糖鎖修飾を受 けている。特に単膜系オルガネラに輸送されるタンパク質 において，その修飾割合は 8 割とも 9 割ともいわれてい る。このように修飾を受けるタンパク質は小胞体上のリボ ソームで合成され，同時に小胞体内腔に輸送される。そこ で小胞体膜に結合したオリゴ糖転移酵素によってコンセン サス配列上のアスパラギン残基の側鎖のアミノ基に 14 糖 からなるオリゴ糖が付加される。付加された 14 糖は小胞 体内の 2 種類のグルコシダーゼ I および II によって，末端 のグルコース残基が取り除かれる。このプロセスは, 小胞 体におけるタンパク質の $N$ 結合型糖鎖プロセシングの最 初のステップである。その後, 正常に糖鎖がプロセシング されたタンパク質はゴルジ体へと輸送される。輸送された 糖タンパク質は, そこでさらにゴルジ体マンノシダーゼに よってプロセシングを受け，複雑な糖鎖構造を獲得し目的 の場所へ輸送され，それぞれの機能を果たすこととなる。 そして機能を果たし寿命を迎えた糖タンパク質の多くはリ ソソームで分解される。

このような糖鎖プロセシングシステムを解明するにあた り，培養細胞レベルでそれら酵素の活性を可視化すること ができれば，それら酵素の機能解明に寄与できると考えて
いる。しかしながら，これら酵素活性を培養細胞レベルで 可視化することは充分に達成されていない。そこで，糖鎖 プロセシングシステム解明の一助となればと思い，糖鎖プ ロセシングに関与する小胞体グルコシダーゼ・ゴルジ体マ ンノシダーゼ・リソソーム フコシダーゼ活性を細胞内で 特異的に高感度に検出可能な蛍光基質の開発を試みてい る。更に, 得られた蛍光基質はこれら酵素の細胞レベルで 作用する阻害剂の探索を可能とする。阻害剂を探索する過 程で頻繁に直面する問題として, in vitro で強力な酵素阻 害活性を示す化合物であっても，培養細胞を用いたアッセ イ系ではほとんど阻害活性を示さないケースが多くある。 この阻害活性の不一致の問題は，培養細胞における化合物 の膜透過性および代謝変換の問題を含み，阻害剂スクリー ニングの効率を大きく低下させていた 1 。本問題を解決す るためにも，蛍光基質は重要であり得られる阻害剤は多く のウイルスに対して抗ウイルス活性を示すことが期待され る $^{1-3)}$ 。

\section{3. 細胞内で機能する蛍光基質の分子設計}

一般に糖鎖プロセシング酵素は特異的な糖鎖構造を認識 して加水分解を行う。そのために，酵素の活性部位には糖 残基を認識するサブサイトが存在する。故にサブサイトは 単糖を認識する程度の空間的大きさしか持っていない場合 が多い。一方，蛍光基質に必須な蛍光団は平面性が高く分 子サイズが単糖よりも大きいため，酵素のサブサイトは立 体的に蛍光団を受け入れがたいことが容易に予想された。 本予想は，基質となる糖残基に蛍光団を直接グリコシル化 する分子設計が適切でないことを意味する。そこで，蛍光 団を酵素の外側へ配置させるために糖残基と蛍光団の間に キノンメチド開裂 (1,6-脱離反応) 部位を設けたプローブ の基本設計を行った (図 1)。有機化学的には，キノンメチ ド開裂が進行することに疑いの余地はないが，細胞中で才 ルガネラ特異的に，しかも効率よく反応が進行するかは確 証が持てなかった。そこで，小胞体に局在するカルボキシ エステラーゼを標的酵素として，本コンセプトの実証実験 を行った。その結果，プローブは酵素の局在する小胞体の みを特異的に蛍光染色したことから，本プローブが細胞中 


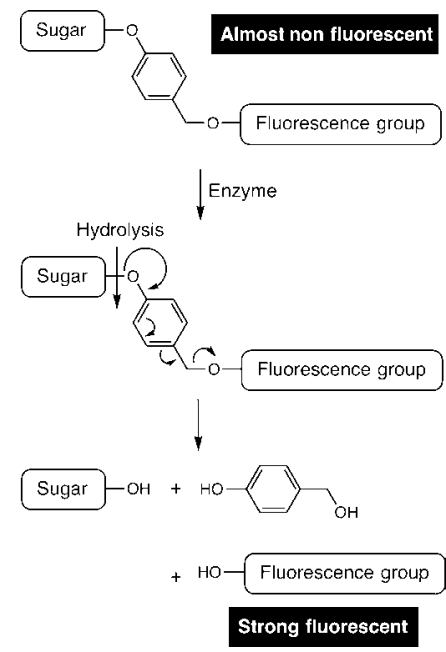

図 1. 加水分解反応後のキノンメチド開裂 (1,6-脱離反応) に 伴った蛍光団遊離機構

で望んだ機能を発揮することが示された4)。

\section{1 小胞体グルコシダーゼの蛍光基質開発}

小胞体にはグルコシダーゼ I と II が存在する。それぞれ の基質特異性の解析を行った結果，小胞体グルコシダーゼ I は糖鎖のみを基質とし，小胞体グルコシダーゼ II は糖鎖 と単糖誘導体の両方を基質とし，2-デオキシグルコシダー ゼ活性も有することが認められた デオキシグルコースとし，赤・青・緑の蛍光団結合させた 3 色のプローブを設計し合成を行った (図 2, 化合物 1)。 これらのプローブは, 酵素の局在する小胞体のみを特異的 に蛍光染色することができだ)。

\section{2 ゴルジ体マンノシダーゼの蛍光基質開発}

細胞内においてマンノシダーゼは小胞体・ゴルジ体・リ ソソームに局在し，それぞれ異なる基質特異性と機能を有 していることが知られている。また，それぞれを別々に蛍 光染色可能なプローブについても報告されていない。そこ で，小胞体グルコシダーゼと同様に，基質を分子設計し合 成を行った (図 2, 化合物 2)。これらのプローブは, 酵素 の局在するゴルジ体のみを特異的に蛍光染色することがで きた。そこで，ゴルジ体分散作用が知られているブレフェ ルジン $\mathrm{A}$ を用いてゴルジ体を分散させると同時に本プ ローブによりゴルジ体を染色した結果, 染色部位が分散さ れたことから, 染色部位がゴルジ体であることを確認し だ)

\section{3 リソソーム フコシダーゼの蛍光基質開発}

細胞内においてフコシダーゼはリソソームに局在し, 様々な糖タンパク質の分解を担っている。そこで, 小胞体 グルコシダーゼと同様に，基質を分子設計し合成を行った (図 2, 化合物 3)。これらのプローブは, 酵素の局在する リソソームのみを特異的に蛍光染色することができた。リ ソソーム肥大作用の知られているクロロキンを作用させ，

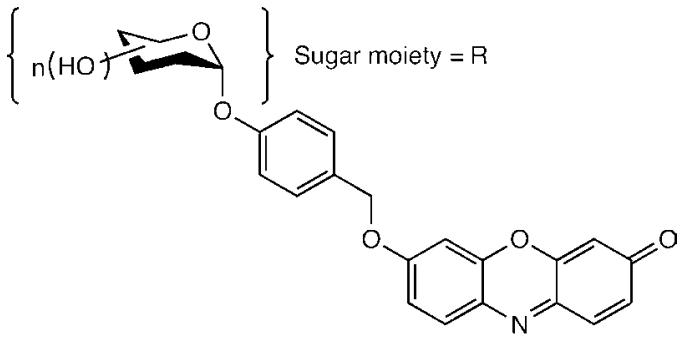

1: $R=2$-Deoxy-glucopyranoside, $2: R=$ Mannopyranoside 3: $\mathbf{R}$ = Fucopyranoside

図 2. 糖鎖プロセシング酵素特異的赤色蛍光基質の構造

化合物 1 は小胞体グルコシダーゼ II 基質, 化合物 2 はゴルジ 体マンノシダーゼ基質, 化合物 $\mathbf{3}$ はリソソームフコシダーゼ基質。

クロロキンの作用により本プローブの染色部位が肥大する か確認した結果，染色部位の肥大が確認されたことから， 染色部位がリソソームであることを確認した ${ }^{8)}$

\section{4. おわりに}

本研究の最終目的の 1 つは，標的酵素特異的な阻害剂を 見出し医薬品候補化合物とすることである。これら阻害剤 をスクリーニングするために，本蛍光基質は有用であると 確信している。現在, 理化学研究所天然化合物バンク (RIKEN NPDepo，MTA 締結済)を活用させていただき， 阻害剤の探索を開始した。杂倠駁な内容となってしまった が, 新規な $N$ 結合型糖鎖阻害剂を得るため, 試行錯誤を 重ねながら研究を行っている。

\section{謝辞}

本研究を行うにあたり, 多くの先生に多大なるご助力を 賜りましたので，ここに感謝の意を表します。

\section{文献}

1 ) W. Hakamata, M. Kurihara, H. Okuda, T. Nishio and T. Oku: Design and screening strategies for $\alpha$-glucosidase inhibitor based on enzymological information. Curr. Top. Med. Chem., 9, 3-12 (2009).

2 ) G. Horne, F.X. Wilson, J. Tinsley, D.H. Williams and R. Storer: Iminosugars past, present and future: medicines for tomorrow. Drug Discov. Today, 16, 107-118 (2011).

3 ) 袴田 航: グリコシダーゼの基質特性解析と阻害剤開発に 関する研究. 応用糖質科学, 1, 51-57 (2011).

4 ) W. Hakamata, A. Machida, T. Oku and T. Nishio: Design and synthesis of an ER-specific fluorescent probe based on carboxylesterase activity with quinone methide cleavage process. Bioorg. Med. Chem. Lett., 21, 3206-3209 (2011).

5 ) W. Hakamata, M. Muroi, T. Nishio, A.T. Oku and A. Takatsuki: Recognition properties of processing $\alpha$-glucosidase I and $\alpha$-glucosidase II. J. Carbohydr. Chem., 23, 27-39 (2004).

6 ) 田村沙緒里, 袴田 航, 平野貴子, 西尾俊幸: 培養細胞に おける小胞体グルコシダーゼII のマルチカラーイメージン グ. 応用糖質科学, 2 Suppl., 34 (2012).

7 ) 鈴木敦子, 袴田 航, 平野貴子, 西尾俊幸 : 七上培養細胞 に扔けるゴルジ体 $\alpha$-マンノシダーゼ選択的蛍光イメージン グプローブの開発. 応用糖質科学, 2 Suppl., 34 (2012).

8 ) 塚越 匠, 袴田 航, 平野貴子, 西尾俊幸: キノンメチド 開裂を基盤とした細胞内フコシダーゼのマルチカラー蛍光 イメージング. 応用糖質科学, 1 Suppl., 60 (2011). 